\title{
Effects of supplemental choline on deposition of cardiac, hepatic and abdominal fat in broiler
}

\author{
ME Hossain*, GB Das \\ Department of Animal Science and Nutrition, Chittagong Veterinary and Animal Sciences University, Khulshi, \\ Chittagong 4225, Bangladesh
}

\begin{abstract}
Two hundred forty Hubbard Classic broiler chicks were used in a 35-day trial to study the effects of supplemental choline on deposition of cardiac, hepatic and abdominal fat in broiler. Birds were fed four types of diet: control diet without choline chloride $\left(T_{0}\right)$, diet containing $0.1 \%$ choline chloride $\left(T_{1}\right), 0.2 \%$ choline chloride $\left(\mathrm{T}_{2}\right)$ and $0.3 \%$ choline chloride. All birds had access to feed and water ad libitum. Results indicated that, trends for deposition of cardiac, hepatic and abdominal fat was decreasing $(\mathrm{P}<0.01)$ in a linear fashion both at $4^{\text {th }}$ and $5^{\text {th }}$ weeks as the level of supplemental choline increased linearly. Maximum deposition of cardiac, hepatic and abdominal fat was observed in birds fed the control diet $\left(T_{0}\right)$ and the mean values were $24.4,34.9$ and 4.1 at $4^{\text {th }}$ week and $41.6,47.8$ and 6.2 at the $5^{\text {th }}$ week. In contrast, minimum deposition of cardiac, hepatic and abdominal fat was observed in birds fed diet supplemented with $0.3 \%$ choline chloride $\left(\mathrm{T}_{3}\right)$ and the mean values were $14.5,19.8$ and 1.74 at $4^{\text {th }}$ week and 27.2, 27.8 and 2.2 at $5^{\text {th }}$ week. It was concluded that increasing levels of supplemental choline substantially reduced deposition of cardiac, hepatic and abdominal fat in commercial broiler.
\end{abstract}

Key words: Abdominal fat, broiler, cardiac fat, choline chloride, hepatic fat

Bangladesh Animal Husbandry Association. All rights reserved. Bang. J. Anim. Sci. 2014.43 (2): 118-122

\section{I ntroduction}

Choline is an emulsifier which mobilizes fat from liver to cell to prevent abnormal accumulation of fat within hepatocytes for healthy liver and gallbladder (Artom 1953a; Artom 1953b). In previous studies, lipotropic action of choline has been interpreted on assumption that fatty acids are carried out from liver to the depots as plasma phospholipides and choline acts by enhancing the synthesis of these compounds in the liver. Since phospholipids have hydrophylic groups and lecithins are the major components of plasma, lecithin was considered as a suitable form for transport of fatty acids in plasma from liver to peripheral tissues. It was also found that, in choline-deficient animals the impairment in the synthesis of lecithins resulted in an accumulation of fat in the liver, either because of a decreased oxidation of fatty acids or because of an inadequate mobilization of phospholipids in the form of plasma lecithins (Artom 1958). It was also explained that oxidation of long chain fatty acids were depressed in liver preparations from choline deficient animals but the ability of the tissue restored the capacity to oxidize the labeled fatty acids at a high rate while choline was administered in vivo (Artom 1953a). These results indicated that the lipotropic effect of choline was due to an increased rate of fatty acid oxidation in the liver. So, there is no doubt that an accumulation of cardiac, hepatic or abdominal fat may result due to either an increased synthesis, a decreased oxidation in the liver, an increased mobilization from depots to the liver or a decreased mobilization of lipid from liver to other tissues (Artom 1960). All these information even though interesting, however, limited to clinical speculations with very small sample size. No systematic experimental evidence has so far been developed with large sample size to explain the effects of supplementing choline chloride in commercial broiler reared under tropical environment maintaining high energy high protein diet. Therefore, the current study aims to observe the effects of supplementing choline chloride on deposition of cardiac, hepatic and abdominal fat in commercial broiler.

\section{Materials and methods}

Two hundred forty day old, unsexed, Hubbard Classic broiler chicks were used for the study purpose in Chittagong Veterinary and Animal 
Sciences University farm, Chittagong, Bangladesh. Initial body weight of the birds averaged $40.6 \mathrm{~g}$. The experiment was carried out following a completely randomized design. The chicks were randomly distributed in four treatment groups having three replications per treatment. Each treatment had 80 birds with 20 birds per replicate (Gomez and Gomez 1984). Birds in individual replicate were treated as the experimental unit and diet was treated as the factor. A bamboo house was constructed for rearing broiler. The house was covered with corrugated sheet. It was bamboo stilted type. The floor of the house was $90 \mathrm{~cm}$ above the ground. Forty five centimeter of the sidewall of the house from floor was made of bamboo and the remaining portion was made of wire net to facilitate proper ventilation. The floor of the house was made of bamboo splits on which fresh dry rice husk was used as litter material at a depth of $4.5 \mathrm{~cm}$. Old litter materials were removed from the pen and new litter was replaced twice a week. Arrangement of floor for rearing broilers was made according to treatments and replications. Compartments were selected for treatment in an unbiased way. The floor of the house was divided by wire net into 12 compartments to maintain desired replication. Birds were brooded under single-tired electric brooder at $95^{\circ} \mathrm{F}, 90^{\circ} \mathrm{F}, 85^{\circ} \mathrm{F}$ and $80^{\circ} \mathrm{F}$ for the $1^{\text {st }}$, $2^{\text {nd }}, 3^{\text {rd }}$ and $4^{\text {th }}$ week respectively by enclosing the compartments with chick guard. The birds were exposed to continuous lighting. Room temperature and humidity was maintained using 200 watt incandescent lamps and exhaust fans.

Table 1. Composition of the diets in different treatments

\begin{tabular}{|c|c|c|c|c|c|c|c|c|}
\hline \multirow{2}{*}{ Ingredient (kg) } & \multicolumn{2}{|c|}{$\mathrm{T}_{0}$} & \multicolumn{2}{|c|}{$\mathrm{T}_{1}$} & \multicolumn{2}{|c|}{$T_{2}$} & \multicolumn{2}{|c|}{$T_{3}$} \\
\hline & Starter & Finisher & Starter & Finisher & Starter & Finisher & Starter & Finisher \\
\hline Maize & 57.4 & 62.0 & 57.4 & 62.0 & 57.4 & 62.0 & 57.4 & 62.0 \\
\hline Rice polish & 4.9 & 3.7 & 4.8 & 3.6 & 4.7 & 3.5 & 4.6 & 3.4 \\
\hline Soybean oil ${ }^{1}$ & 1.9 & 3.5 & 1.9 & 3.5 & 1.9 & 3.5 & 1.9 & 3.5 \\
\hline Soybean meal & 26.0 & 21.5 & 26.0 & 21.5 & 26.0 & 21.5 & 26.0 & 21.5 \\
\hline Protein concentrate ${ }^{2}$ & 7.5 & 7.0 & 7.5 & 7.0 & 7.5 & 7.0 & 7.5 & 7.0 \\
\hline Lime stone $^{3}$ & 0.8 & 0.8 & 0.8 & 0.8 & 0.8 & 0.8 & 0.8 & 0.8 \\
\hline Dicalcium phosphate ${ }^{4}$ & 0.8 & 0.8 & 0.8 & 0.8 & 0.8 & 0.8 & 0.8 & 0.8 \\
\hline L-Lysine & 0.1 & 0.1 & 0.1 & 0.1 & 0.1 & 0.1 & 0.1 & 0.1 \\
\hline DL-Methionine & 0.05 & 0.05 & 0.05 & 0.05 & 0.05 & 0.05 & 0.05 & 0.05 \\
\hline Choline chloride & - & - & 0.1 & 0.1 & 0.2 & 0.2 & 0.3 & 0.3 \\
\hline Vit-min. premix ${ }^{5}$ & 0.25 & 0.25 & 0.25 & 0.25 & 0.25 & 0.25 & 0.25 & 0.25 \\
\hline Common salt & 0.3 & 0.3 & 0.3 & 0.3 & 0.3 & 0.3 & 0.3 & 0.3 \\
\hline \multicolumn{9}{|l|}{ Calculated value } \\
\hline ME Kcal (kcal/kg) & 3003 & 3153 & 3000 & 3150 & 3004 & 3155 & 3001 & 3152 \\
\hline $\mathrm{CP}(\%)$ & 22.1 & 20.0 & 22.1 & 20.0 & 22.1 & 20.0 & 22.1 & 20.0 \\
\hline Crude fibre (\%) & 3.3 & 3.0 & 3.3 & 3.0 & 3.3 & 3.0 & 3.3 & 3.0 \\
\hline Ether extract (\%) & 5.3 & 6.8 & 5.3 & 6.8 & 5.3 & 6.8 & 5.3 & 6.8 \\
\hline Calcium (\%) & 1.1 & 1.1 & 1.1 & 1.1 & 1.1 & 1.1 & 1.1 & 1.1 \\
\hline Phosphors (\%) & 0.8 & 0.7 & 0.8 & 0.7 & 0.8 & 0.7 & 0.8 & 0.7 \\
\hline Avail phos (\%) & 0.4 & 0.4 & 0.4 & 0.4 & 0.4 & 0.4 & 0.4 & 0.4 \\
\hline Lysine (\%) & 1.4 & 1.3 & 1.4 & 1.3 & 1.4 & 1.3 & 1.4 & 1.3 \\
\hline Methionine (\%) & 0.5 & 0.5 & 0.5 & 0.5 & 0.5 & 0.5 & 0.5 & 0.5 \\
\hline Cyst+Meth (\%) & 0.9 & 0.8 & 0.9 & 0.8 & 0.9 & 0.8 & 0.9 & 0.8 \\
\hline Tryptophan (\%) & 0.3 & 0.3 & 0.3 & 0.3 & 0.3 & 0.3 & 0.3 & 0.3 \\
\hline
\end{tabular}

$\mathrm{T}_{0}$, control diet; $\mathrm{T}_{1}$, diet containing $0.1 \%$ choline chloride; $\mathrm{T}_{2}$, diet containing $0.2 \%$ choline chloride; $\mathrm{T}_{3}$, diet containing $0.3 \%$ choline chloride; ${ }^{1} \mathrm{ME}=8900 \mathrm{kcal} / \mathrm{kg}$, Ether extracts $=99.9 \% ;{ }^{2} \mathrm{DM}=92.5 \%, \mathrm{ME}=2900 \mathrm{kcal} / \mathrm{kg}$ $\mathrm{DM}, \mathrm{CP}=60.0 \%, \mathrm{CF}=3.0 \%, \mathrm{EE}=13.0 \%, \mathrm{Ash}=24.0 \%, \mathrm{Ca}=6.5 \%, \mathrm{P}=2.5 \%$, Lysine $=7.0 \%$, Methionine $=2.0 \%$; ${ }^{3} \mathrm{DM}=98.9 \%, \mathrm{Ca}=35.8 \%, \mathrm{P}=0.02 \% ;{ }^{4} \mathrm{DM}=98.0 \%, \mathrm{Ca}=24.3 \%, \mathrm{P}=18.2 \%$; ${ }^{5}$ Vitamin mineral premix each $500 \mathrm{~g}$ contains: vitamin $A=8.0 \mathrm{MIU}, D_{3}=2.0 \mathrm{MIU}$, vitamin $E=20 \mathrm{~g}$, vitamin $K_{3}=3.0 \mathrm{~g}$, vitamin $B_{1}=3.0 \mathrm{~g}$, vitamin $B_{2}=4.0 \mathrm{~g}$, vitamin $B_{6}=3.0 \mathrm{~g}$, vitamin $B_{12}=0.015 \mathrm{~g}$, niacin $=20.0 \mathrm{~g}$, folic acid $=1.0 \mathrm{~g}$, biotin $=0.08 \mathrm{~g}$, iron $=30.0 \mathrm{~g}$, zinc $=40 \mathrm{~g}$, manganese $=40 \mathrm{~g}$, copper $=5.0 \mathrm{~g}$, l odine $=1.0 \mathrm{~g}$, selenium $=0.15 \mathrm{~g}$ 


\section{Choline effect on fat deposition in Broiler}

Ground feed ingredients, vitamin mineral premix and feed additives used in the ration (Table 1 ). Mash diets were prepared by hand mixing. At first, major ingredients were thoroughly mixed then micro-ingredients were added. Birds had unrestricted access to feed and water. Feed and water were supplied to the birds by plastic hanging feeder and bell type drinker. Four rations designated as $T_{0}, T_{1}, T_{2}$ and $T_{3}$ were formulated where $T_{1}, T_{2}$ and $T_{3}$ was supplemented with $0.1 \%, 0.2 \%$ and $0.3 \%$ choline chloride and $\mathrm{T}_{0}$ was the control (without choline) group. Nutrient density in the experimental diet was maintained according to Singh (1980). Formulated diets were analyzed as per AOAC (1980). The starter diet was fed for the first two weeks and the finisher diet was fed for the remaining periods.

The slated floor and cages were cleaned and disinfected with phenyl solution. The room was fumigated overnight using potassium permanganate and formaldehyde. Feeders and drinkers were cleaned and disinfected with phenyl solution and dried and left for 3 days before arrival of the chicks. Foot bath containing potassium permanganate was placed in front of the shed. The birds were vaccinated against New castle and Gumboro disease on the $4^{\text {th }}$ and $10^{\text {th }}$ day followed by a booster dose on 20th and $25^{\text {th }}$ day. No outbreak of infectious diseases was found throughout the whole experimental period.

At the end of $4^{\text {th }}, 5^{\text {th }}$ and $6^{\text {th }}$ week of the experiment, $25 \%$ of the birds from each replication weighing close to the average of the pen were selected and slaughtered by cervical dislocation for processing. Feed and water were withdrawn 4 hours prior to slaughtering to empty the digestive system with less chance of damaging the intestines and contaminating the carcass with fecal materials. Carcass was subjected to dissection following Jones (1984) method. Carcass weight was recorded after removal of feather, feet, head and viscera. Hot carcass weight was recorded immediately after evisceration. Hearts and livers were collected and sliced into small pieces and subjected to hot air oven for estimation of dry matter. Dried slices were ground to powder. Cardiac and hepatic fat was extracted by using soxtec apparatus (AOAC 1997).
Data related to weight gain, feed intake, FCR and carcass characteristics were compiled by using Microsoft excel 2007 and analyzed for ANOVA by using Stata (2009) for comparison of mean. SPSS (2007) was used for partitioning multiple mean in homogenous subset. Means showing significant differences were compared by Duncan's New Multiple Range Test (Duncan 1955). Statistical significance was accepted at $5 \%$ level $(p<0.05)$.

\section{Results and Discussion}

Supplementation of choline substantially decreased $(p<0.01)$ cardiac, hepatic and abdominal fat (Table 2). As the level of choline chloride increased from 0 to $0.3 \%$, cardiac, hepatic and abdominal fat decreased from 24.4 to $14.5,34.9$ to 19.8 and 4.1 to 1.74 , respectively, at $4^{\text {th }}$ week. Similar to $4^{\text {th }}$ week, cardiac, hepatic and abdominal fat decreased from 41.6 to 27.2 47.8 to 27.8 and 6.2 to 2.2 , respectively, at $5^{\text {th }}$ week. At $4^{\text {th }}$ week, maximum deposition of cardiac (24.4), hepatic (34.9) and abdominal (4.1) fat was recorded in birds fed control diet $\left(T_{0}\right)$. At $5^{\text {th }}$ week, the result showed similar trend.

Table 2. Deposition of cardiac, hepatic and abdominal fat at $4^{\text {th }}$ and $5^{\text {th }}$ week of age

\begin{tabular}{lcccc}
\hline & \multicolumn{4}{c}{ Dietary treatment groups } \\
\cline { 2 - 5 } & $\mathrm{T}_{0}$ & $\mathrm{~T}_{1}$ & $\mathrm{~T}_{2}$ & $\mathrm{~T}_{3}$ \\
\hline Cardiac fat at & $24.4^{\mathrm{a} \pm 2.1}$ & $19.7^{\mathrm{b}} \pm 1.8$ & $17.3^{\mathrm{b}} \pm 1.7$ & $14.5^{\mathrm{b}} \pm 2.2$ \\
$4^{\text {th }}$ wk (\%) & & & & \\
\hline Cardiac fat at & $41.6^{\mathrm{a}} \pm 2.0$ & $35.0^{\mathrm{b}} \pm 1.6$ & $34.1^{\mathrm{b}} \pm 2.4$ & $27.2^{\mathrm{c}} \pm 1.7$ \\
$5^{\text {th }}$ wk (\%) & & & & \\
\hline Hepatic fat at \\
$4^{\text {th }}$ wk (\%)
\end{tabular}

$\mathrm{T}_{0}$, diet without choline chloride; $\mathrm{T}_{1}$, diet containing $0.1 \%$ choline chloride; $\mathrm{T}_{2}$, diet containing $0.2 \%$ choline chloride; $\mathrm{T}_{3}$, diet containing $0.3 \%$ choline chloride; means with different superscript in the same row differed significantly $(p<0.01)$ 
Kubena et al. (1974) conducted trials to study the effects of rearing temperature, sex, age or weight, and dietary choline chloride and inositol supplementation on the quantity of abdominal fat in broilers. They did not find significant difference in deposition of abdominal fat within each sex. However, females had a larger percentage of abdominal fat than the males. Similar results were obtained by Rama Rao et al. (2001) who reported that, supplementation of choline up to $760 \mathrm{mg} / \mathrm{kg}$ didn't have any significant effect in reducing of abdominal fat. The results of the current study, however, were quite contradictory. Supplementation of choline significantly decreased abdominal fat in broiler. The reason could be that the level of choline used in the present study was much higher (up to $3000 \mathrm{mg} / \mathrm{kg}$ ) in comparison to earlier studies. However, the mode of mobilization of fats from those organs due to supplementation of choline is unclear.

In the current study, higher concentration of metabolizable energy (3150-3155 kcal/kg) supplied at $4^{\text {th }}$ and $5^{\text {th }}$ weeks of age stimulated rapid deposition of cardiac, hepatic and abdominal fat in the control group $\left(T_{0}\right)$. The decreasing trend for deposition of cardiac, hepatic and abdominal fat with increasing levels of choline chloride supplementation might be due to the fact that choline initiated mobilization of fat from those organs. The argument is in line with Artom (1958) who stated that, supplementation of choline could reduce the amount of fat in the liver. In fact, broiler diets formulated with high fat may stimulate choline deficiency by increasing more dietary requirement for choline. This is particularly important for chicks during earlier stages of their life, since they are unable to synthesize choline until 13 weeks of age.

Administration of choline to rats fed low-protein diets enhanced the oxidation of fatty acids in vitro (Artom 1956). This effect was accompanied by decrease in the amount of fat and increase in the rate of synthesis of liver lecithins. It suggested that, choline could act on fatty acid oxidation since it promoted lecithin formation. However, such relationships were not maintained in a straight forward manner. In fact, low-lecithin levels together with low-fat contents and a high rate of fatty acid oxidation was found in the livers of protein-deficient rats receiving diethanolamine (Artom 1953a). Although enhancements of fatty acid oxidation due to administration of choline was obtained in vitro by supplementing lowprotein diets with cystine, or tocopherol, however, fat continued to accumulate in the liver (Artom 1953a). It could therefore be inferred that, the lipotropic action of choline could not be explained merely as the reflection of an enhanced oxidation of fatty acids in the liver.

Recent studies have shown that the unesterified fatty acids of the blood are the major form in which fats are transported. Therefore, the type of relationship between concentrations of cholinecontaining phospholipids in the liver and the amount of fatty acids oxidized is mysterious. Because, administration of choline in vivo stimulated both the synthesis of phospholipids as well as the oxidation of fatty acids in the liver (Artom 1953a). It could therefore be inferred that, perhaps choline promotes the formation of some lecithin containing lipoproteins in the liver, which are important either for maintaining the spatial configuration of enzymes in mitochondria or may be, these lipoproteins synthesized in the liver, could represent the form in which fatty acids are carried away from liver to the depots. Therefore, as the level of supplemental choline increased linearly, deposition of cardiac, hepatic and abdominal fat decreased in the same fashion.

\section{Conclusion}

Supplementation of choline substantially reduces cardiac, hepatic and abdominal fat in commercial broiler. It could therefore be concluded that, choline chloride could be supplemented at a rate of $0.2-0.3 \mathrm{~g} / 100 \mathrm{~g}$ to improve lean carcass yield and reduce deposition of saturated fats in commercial broiler.

\section{Acknowledgements}

We acknowledge University Grants Commission (UGC), Bangladesh for financial support to the project. 


\section{Choline effect on fat deposition in Broiler}

\section{References}

AOAC (1997). Official Methods of Analysis. Vol. I. $15^{\text {th }}$ Ed., Association of Official Analytical Chemists, Arlington, VA.

Artom C (1953a). Role of choline in the oxidation of fatty acids by the liver. Journal of Biological Chemistry, 205: 101-11.

Artom C (1953b). Role of choline in the oxidation of fatty acids by the isolated liver. Nature, 171: 347-8.

Artom C (1955). Effect of choline administration on the oxidation of fatty acids by extrahepatic tissues. Journal of Biological Chemistry, 213: 681-687.

Artom C (1956). Effects of some dietary factors on the metabolism of fatty acids in liver preparations. Journal of Biological Chemistry, 223: 389 - 398.

Artom C (1958). Role of choline in the hepatic oxidation of fat. American J ournal of Clinical Nutrition, 6: 221-34.

Artom C (1960). Mechanism of action of choline. American Journal of Clinical Nutrition, 8: 303-5.

Best $\mathrm{CH}$, Hersheyandm JM and Huntsman E (1932). Effect of lecithin on fat deposition in the liver. American Journal of Physiology, 101: 7.

Duncan DB (1955). Multiple range and multiple 'F' test. Biometrics, 11: 1-42.

Gomez AK and Gomez AA (1984). Statistical procedures for Agricultural Research. $2^{\text {nd }}$ Edition, J ohn Willy and Sons, New York.
Jones R (1984) A standard method of dissection of poultry for carcass analysis. Technical Bulletin No. 222, West of Scotland Agricultural College, Scotland.

Jukes TH (1947). Choline. Annual Review of Biochemistry, 16: 193.

Kubena LF, Deaton JW, Chen TC and Reece FN (1974). Factors influencing the quality of abdominal fat in broilers. 1. Rearing temperature, sex, age or weight, and dietary choline chloride and inositol supplementation. Poultry Science, 53: 211214.

Mcnamara DJ (1992). Dietary fatty acids, lipoproteins, and cardiovascular disease. Advanced Food and Nutrition Research, 36: 253-351.

Rama Rao SV, Sunder GS, Reddy MR, Praharaj NK, Raju MV and Panda AK (2001). Effect of supplementary choline on the performance of broiler breeders fed on different energy sources. British Poultry Science, 42: 362367.

Singh RA (1980). Poultry Production. $3^{\text {rd }}$ Ed., Kalyani Publishers, 102b, Ramanath Mazumder Street, Ballygunj, Kolkata, 700019.

SPSS (2007). SPSS for Windows, Version 16.0,SPSS Inc, Chicago.

Stata (2009). Stata Statistical Software, Version 11C, TX: StataCorp LP, College Station, USA. 